\title{
MANAJEMEN REDAKSI PROGRAM BERITA KOMPAS TV MAKASSAR
}

\author{
Muhammad Yusuf AR 1, Ashari Nurlansyah2 \\ 1Fakultas Ilmu Ekonomi dan Ilmu-ilmu Sosial, Universitas Fajar \\ email: jusufar@gmail.com \\ 2Fakultas Ilmu Ekonomi dan Ilmu-ilmu Sosial, Universitas Fajar \\ email: asharinurlansyah@ymail.com
}

\begin{abstract}
Abstrak
Rumusan permasalahan dalam penelitian ini adalah "Bagaimana manajemen redaksi program berita Kompas TV Makassar, ditinjau dari fungsi manajemen menurut George R. Terry." Dengan demikian, tujuan penelitian ini, untuk mengetahui bagaimana manajemen redaksi program berita di Kompas TV Makassar, dalam kaitannya dengan penerapan fungsi-fungsi manajemen, yakni: planning, organizing, actuating, controlling (POAC).

Penelitian ini menggunakan metode penelitian deskriptif dengan pendekatan kualitatif. Objek penelitiannya adalah Divisi Pemberitaan Kompas Tv Makassar. Hasil penelitian ini menunjukkan bahwa tidak ada fungsi manajemen lebih menonjol di antara yang lainnya. Namun komitmen pada lembaga rapat redaksi sebagai forum pengambilan keputusan tertinggi atas isu liputan, pembentukan tim liputan, rencana eksekusi di lapangan, dan seluruh perencanaan serta hasil evaluasi, merupakan sebuah keharusan bagi seluruh kru divisi pemberitaan Kompas Tv Makassar.
\end{abstract}

Kata Kunci: Manajemen Penyiaran, Kompas Tv Makassar, Program Berita Tv.

\section{PENDAHULUAN}

\section{Latar Belakang}

Perusahaan media sangat membutuhkan manajemen sebagai alat kontrol dalam usaha mengemukakan ide, proses pengumpulan informasi hingga proses penayangan (Fachruddin, 2016: 18). Termasuk dalam proses kerja redaksional, manajemen sangat dibutuhkan untuk mengatur sistem kerja agar tujuan dapat tercapai sesuai yang diharapkan.

Media massa pada umumnya, baik cetak maupun audio visual, menempatkan berita sebagai faktor utama. Berita menjadi tujuan utama dari media komunikasi, mengingat berita sudah menjadi salah satu kebutuhan mendesak 
untuk segera terpenuhi. Karena hal itu pulalah, kita dihadapkan pada konsep mengenai masyarakat informasi (information society).

Saat ini telah banyak bermunculan stasiun-stasiun televisi baru, baik televisi lokal maupun yang berkedudukan di Jakarta. Dunia pertelevisian Indonesia pun menjadi berkembang dengan cepat, baik dari aspek teknologi maupun acara-acara yang disajikan. Suasana kerja pada stasiun televisi terkadang penuh ketegangan, khususnya menjelang suatu program akan ditayangkan, sehingga diperlukan kesigapan dan kecepatan kerja karena dikejar-kejar tenggat waktu (deadline). Komunikasi yang cepat merupakan hal vital dalam redaksi pemberitaan sebuah televisi (Askurifai Baksin, 2006: 27-28).

Redaksi pemberitaan suatu stasiun televisi setiap harinya menerima puluhan, bahkan ratusan informasi yang berasal dari berbagai sumber. Ruang redaksi harus benar-benar cermat dalam menentukan berita mana yang dibutuhkan atau menarik bagi pemirsanya. Berbagai informasi tersebut harus disaring untuk menentukan berita mana yang layak ditayangkan. Seorang produser atau redaktur program berita dituntut memiliki kemampuan untuk melakukan news judgement, karena tanpa kemampuan ini, suatu program berita televisi hanya akan menyajikan berita-berita yang tidak saling berhubungan, bahkan membosankan.

Ruang redaksi harus benar-benar cermat menentukan berita mana yang dibutuhkan atau menarik bagi pemirsanya. Berbagai informasi tersebut harus disaring untuk menentukan berita yang layak ditayangkan. Dalam menentukan berita yang ditawarkan ke redaksi akan melalui tahap seleksi. Tahap penyeleksian ini dilakukan oleh produser, agar berita-berita yang ditawarkan ke redaksi sesuai standar kebijakan yang telah ditetapkan oleh stasiun televisi tersebut. Di sinilah pentingnya sebuah manajemen pemberitaan.

Manajemen pemberitaan adalah proses pengelolaan materi pemberitaan melalui tahap-tahap perencanaan, pengorganisasian, penggerakan, dan pengawasan, yang mencakup proses peliputan, penulisan, sampai pada editing hingga menjadi berita yang layak untuk ditayangkan. Salah satu stasiun televisi swasta di Indonesia yang banyak menayangkan edukasi dan informasi adalah Kompas TV. Stasiun televisi swasta ini memiliki biro pemberitaan di Makassar.

Kompas TV Makassar selain menayangkan siaran relai dari Kompas TV pusat (Jakarta), juga memiliki lima program lokal yang tayang setiap hari, yaitu: (1) I Love Makassar (2) Embun Qalbu (3) Jappa-Jappa (4) Kompas Sulsel Pagi, dan (5) Kompas Sulsel Sore. Dari kelima program diatas "Kompas Sulsel Pagi dan Kompas Sulsel Sore" merupakan program berita harian.

\section{Perumusan Masalah}

Adapun rumusan masalah penelitian ini adalah: Bagaimana manajemen redaksi program berita Kompas TV Makassar, ditinjau dari empat fungsi manajemen planning, organizing, actuating, controlling (POAC)?

\section{Tujuan Penelitian}

Tujuan penelitian ini adalah untuk mengetahui bagaimana manajemen redaksi program berita di Kompas TV Makassar, dalam kaitannya dengan penerapan 
empat fungsi manajemen; planning, organizing, actuating, controlling (POAC).

\section{Manfaat Penelitian}

Sebagai salah satu referensi dalam studi mengenai manajemen program berita televisi (studi broadcasting). Penelitian ini diharapkan pula menjadi masukan baru bagi pengelola televisi berita, terutama stasiun televisi yang memiliki kantor biro di daerah.

\section{Tinjauan Pustaka}

\section{Manajemen}

Schoderbek, Cosier, dan Aplin mendefinisikan Manajemen sebagai: A process of achieving organizational goal through others (suatu proses untuk mencapai tujuan organisasi melalui pihak-pihak lain. (Morissan, 2008: 127). Sedangkan George R Terry mendefinisikan manajemen dalam bukunya "Principles of Management" sebagai proses yang membedakan atas perencanaan, pengorganisasian, penggerakan, dan pengawasan dengan memanfaatkan baik ilmu maupun seni demi mencapai tujuan yang telah ditetapkan sebelumnya. Berikut ini fungsi manajemen menurut Terry:

1) Perencanaan (planning), sebagai dasar pemikiran dari tujuan dan penyusunan langkah-langkah yang akan dipakai untuk mencapai tujuan. Merencanakan berarti mempersiapkan segala kebutuhan, memperhitungkan matang-matang apa saja yang menjadi kendala, dan merumuskan bentuk pelaksanaan kegiatan yang bermaksuud untuk mencapai tujuan.

2) Pengorganisasian (organization), sebagai cara mengumpulkan orang-orang dan menempatkan mereka menurut kemampuan dan keahliannya dalam pekerjaan yang sudah direncanakan.

3) Penggerakan (actuating), menggerakan organisasi agar berjalan sesuai pembagian kerja masing-masing, serta menggerakan seluruh sumber daya yang ada dalam organisasi agar pekerjaan atau kegiatan yang dilakukan bisa berjalan sesuai rencana serta memcapai tujuan.

4) Pengawasan (controlling), mengawasi apakah gerakan dari organisasi ini sudah sesuai dengan rencana atau belum. Serta mengawasi penggunaan sumber daya dalam organisasi, agar bisa terpakai secara efektif dan efisien tanpa melenceng dari rencana. Hakikat dari fungsi manajemen menurut Terry adalah apa yang direncakan, itu yang akan dicapai. (http://studimanajemen.blogspot.co.id/2012/08/fungsimanajemen-menurut-george-terry.html, diakses pada 22 Mei 2016).

\section{Program Berita Televisi}

Sebuah format acara televisi yang diproduksi berdasarkan informasi dan fakta atas kejadian dan peristiwa yang berlangsung pada kehidupan masyarakat sehari-hari, baik yang bersifat time less atau time concern (Anton Mabruri KN, 2013: 32). Program berita merupakan salah satu bagian penting dalam penyelenggaraan suatu stasiun penyiaran. Dalam struktur organisasi umum suatu stasiun penyiaran, pemberitaan termasuk dalam divisi programming. Namun, karena kekhususannya, 
bagian pemberitaan berkembang menjadi suatu divisi yang berdiri sendiri. Berita menurut Prof Mitche V. Charnely, sebagaimana dikutip Eva Arifin (2010: 69) adalah: "News the timely report of facts or opinion of either interest or importance, or both to considerable number of people". Berita merupakan laporan tercepat mengenai fakta atau opini penting atau menarik, atau kedua-duanya, bagi kebanyakan orang.

\section{Kompas TV Makassar}

Kompas Tv Makassar sebelumnya bernama Makassar Tv yang merupakan stasiun televisi lokal pertama di kota Makassar, Sulawesi Selatan. Pada Tahun 2011, Makassar TV menjalin kolaborasi dengan Kompas TV, anak perusahaan Kompas Gramedia grup. Hal ini terkait peraturan Komisi Penyiaran Indonesia (KPI), tentang kewajiban TV Nasional untuk berjejaringan dengan TV Lokal. Sejak memutuskan untuk berjejaringan, Makassar TV pun berubah menjadi Kompas Makassar TV, dengan motto 'Inspirasi Makassar, Inspirasi Indonesia'. Kompas TV Makassar melalui stasiun pemancar di Bilibili, dengan kanal 23 UHF meliputi: Makassar, Gowa, Maros, Pangkep, Barru, dan Takalar. (http://www.makassartv.co.id/semua-company.html, diakses pada 16 Mei 2016, pukul 19:00 Wita).

\section{Manajemen Penyiaran}

Mengelola bisnis media penyiaran merupakan salah satu bisnis yang paling sulit dan paling menantang dibandingkan dengan jenis industri lainnya. Mengelola media penyiararan pada dasarnya adalah mengelola manusia. Keberhasilan media penyiaran sejatinya ditopang oleh kreativitas manusia yang bekerja pada tiga pilar utama sebagai fungsi vital yang dimiliki setiap media penyiaran yaitu teknik, program, dan pemasaran.

Keberhasilan media penyiaran bergantung pada bagaimana kualitas orang-orang yang bekerja pada ketiga bidang tersebut. Namun demikian, kualitas manusia saja tidak cukup jika tidak disertai dengan kemampuan pimpinan media penyiaran bersngkutan mengelola sumber daya manusia yang ada. Karena alasan inilah manajemen yang baik mutlak diperlukan pada media penyiaran. (Morissan, 2008:133).

\section{Tingkatan Manajemen}

Level atau tingkatan manajamen juga terdapat pada pengelolaan stasiun televisi. Pada media penyiaran dan juga perusahaan lainnya, umumnya posisi manajer biasanya terdiri atas tiga tingkatan (level) yaitu:

1. Manajer tingkat bawah (lower level manager)

Manajer pada tingkat ini bertugas mengawasi secara dekat pekerjaan rutin karyawan yang berada dibawah naungannya. Manajer tingkat bawah bertanggung jawab kepada manajer tingkat menengah. Misalnya pada stasiun televisi, seorang manajer produksi bertanggung jawab kepada manajer program.

2. Manajer tingkat menengah (middle manager) 
Melaksanakan kegiatan tertentu sebagai bagian dari proses untuk mencapai tujuan utama perusahaan. Para manajer menengah membawahi dan mengarahkan kegiatan-kegiatan para manajer lainnya dan kadang-kadang juga karyawan operasional. Pada stasiun penyiaran, kepala departemen penjualan, program, berita, teknik dan bisnis merupakan tangkat menengah.

3. Manajer puncak (top manager)

Mengoordinasikan kegiatan perusahaan serta memberikan arahan dan petunjuk umum untuk mencapai tujuan perusahaan. Sebutan khas bagi manajer puncak adalah direktur atau presiden direktur. (Morissan, 2008:137138).

\section{Kerangka Pemikiran}

Dalam Penelitian ini, peneliti mengaitkan dengan fungsi-fungsi manajemen pada media penyiaran, yaitu: planning, organizing, actuating, controlling.

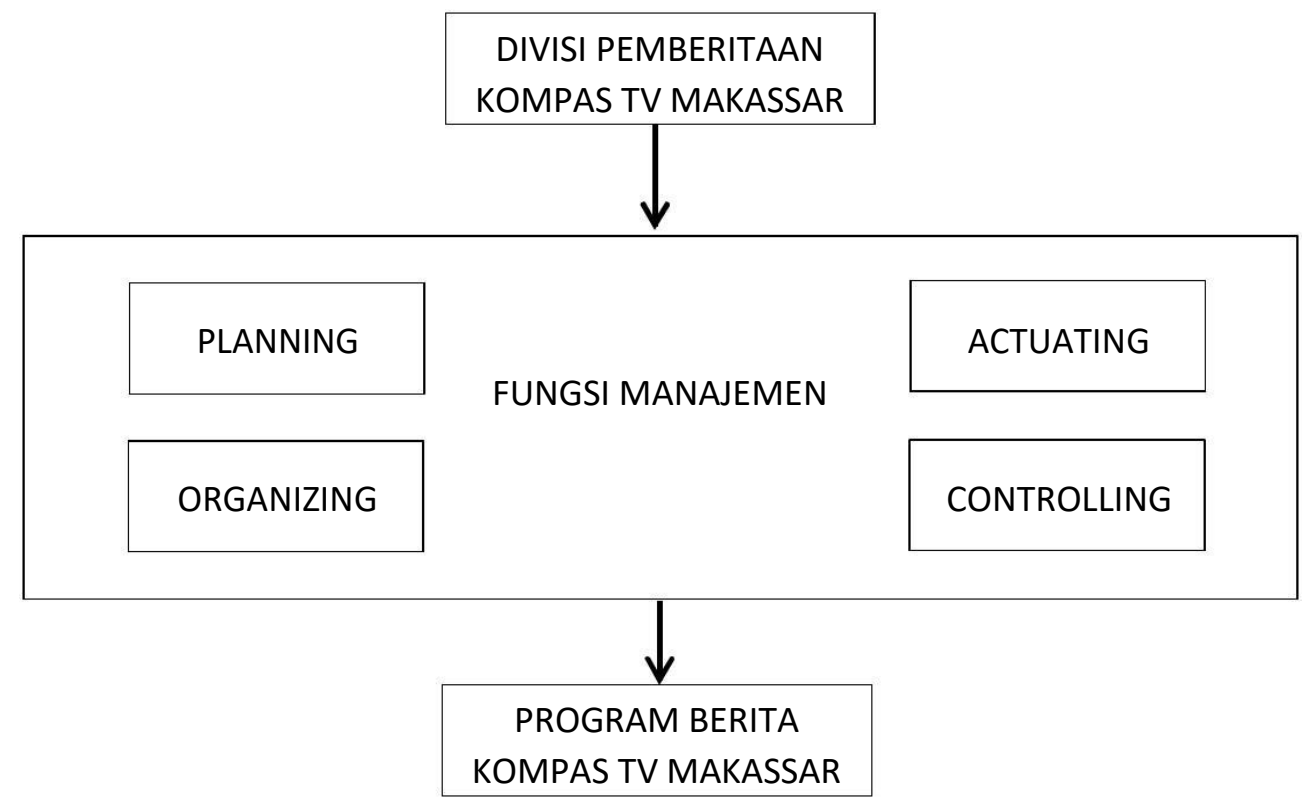

\section{METODE PENELITIAN}

\section{Lokasi dan Waktu Penelitian}

Penelitian ini berlangsung di Makassar pada rentang waktu Maret hingga Mei 2016.

\section{Tipe Penelitian}

Penelitian ini menggunakan metode penelitian deskriptif dengan pendekatan kualitatif. Penelitian kualitatif bertujuan memperoleh gambaran seutuhnya mengenai suatu hal menurut pandangan manusia yang diteliti. Penelitian kualitatif berhubungan dengan ide, persepsi, pendapat atau kepercayaan orang yang diteliti 
dan kesemuanya tidak dapat diukur dengan angka. Penelitian kualitatif menurut Moleong (2007: 6) bermaksud untuk memahami fenomena tentang apa yang dialami oleh subjek penelitian misalnya perilaku, persepsi, motivasi, tindakan, dll., secara holistik, dan dengan cara deskripsi dalam bentuk kata-kata dan bahasa, pada suatu konteks khusus yang alamiah dan dengan memanfaatkan berbagai metode alamiah. Menurut Bogdan dan Taylor (Moleong, 2007:4), metodologi kualitatif sebagai prosedur penelitian yang menghasilkan data deskriptif berupa kata-kata tertulis atau lisan dari orang-orang dan perilaku yang dapat diamati.

\section{Objek Penelitian}

Objek penelitian ini adalah Divisi Pemberitaan Kompas Tv Makassar. Penelitian ini dilakukan satu bulan sejak Kompas Tv menyatakan diri sebagai televisi berita pada 28 Januari 2016. Kota Makassar menjadi salah satu bagian dari jaringan Kompas TV yang berkolaborasi dengan televisi lokal bernama Makassar TV, yang merupakan stasiun televisi lokal pertama di Makassar.

\section{Informan Penelitian}

Informan adalah orang yang berada pada lingkup penelitian, artinya orang yang dapat memberikan informasi tentang situasi dan kondisi latar penelitian. Jadi ia harus banyak pengalaman tentang penelitian dan secara sukarela menjadi anggota tim meskipun tidak secara formal. Mereka dapat memberikan pandangannya dari dalam tentang nilai-nilai, sikap, bangunan, proses dan kebudayaan yang menjadi latar penelitian setempat. Oleh karena itu, penelitian ini melibatkan beberapa informan yaitu: Kepala Biro Kompas TV Makassar Saffri Sitepu, Maya Ochtaria eksekutif produser sekaligus produser program berita "Kompas Sulsel Pagi "dan Kompas Sulsel Sore", Muhammad Taufik Asdar Kordinator Liputan Kompas TV Makassar, Rama Pratama video jurnalis Kompas TV Makassar, dan Niluh Puspa reporter sekaligus presenter di Kompas TV Makassar.

\section{Sumber Data}

\section{Data primer}

Data primer merupakan data yang berasal dari sumber data utama, berwujud tindakan-tindakan dan kata-kata dari pihak terlibat dengan objek yang diteliti (Moleong, 2009: 112). Data ini diperoleh dan dikumpulkan dari lapangan dengan melakukan wawancara kepada beberapa informan.

2. Data sekunder

Data yang diperoleh secara tidak langsung dari objek yang diteliti, yaitu dengan cara mengambil dokumentasi data langsung dari lokasi penelitian di Kompas Tv Makassar, dan lain-lain yang mengenai informan terkait dengan penelitian primer.

\section{Teknik Pengumpulan Data}

Teknik pengumpulan data yang digunakan dalam penelitian ini adalah:

\section{a. Literatur}

Dalam pelaksanaan kegiatan pengumpulan data, penulis selalu melakukan riset data untuk mencari informasi yang penulis butuhkan. Penulis menggunakan studi literatur, baik melalui internet maupun buku sebagai sumber informasi terbaru. 
b. Interview

Interview atau wawancara merupakan teknik pengumpulan data dengan mengajukan pertanyaan secara langsung kepada narasumber atau pihak yang dianggap berkompeten.

c. Observasi Partisipan

Penulis melihat dan terlibat secara langsung dalam manajemen produksi program berita Kompas Tv, dari perencanaan, koordinasi, pelaksanaan program, hingga penayangannya.

\section{Validitas Data}

1) Penelitian ini menggunakan teknik triangulasi. Triangulasi merupakan teknik pemeriksaan keabsahan data dengan melakukan pengecekan atau membandingkan data tersebut.

2) Teknik triangulasi yang digunakan oleh peneliti adalah triangulasi data (sumber). Triangulasi data berarti membandingkan dan mengecek balik derajat suatu informasi yang diperoleh melalui waktu dan alat yang berbeda dalam metode kualitatif.

\section{Teknik Analisis Data}

Penelitian deskriptif adalah penelitian yang tidak dimaksudkan untuk menguji hipotesis berdasarkan teori-teori tertentu. Data yang diperoleh dan dikumpulkan dari berbagai sumber kemudian ditelaah dalam upaya peningkatan pemahaman terhadap objek yang diteliti. Teknis analisis yang digunakan dalam penelitian ini adalah analisis data interaktif (Miles dan Haberman dalam Sutopo, 2002: 37).

\section{Definisi Operasional}

Ada beberapa kata atau istilah yang memerlukan penjelasan lebih lanjut dalam judul penelitian ini, antara lain:

1) Manajemen Redaksional. Dalam penelitian ini, dimaksudkan sebagai sebuah kegiatan manajerial pada sebuah ruang redaksi biro pemberitaan Kompas Tv. Bagaimana fungsi-fungsi manajemen berlangsung dalam mengelola sebuah program berita, sejak perencanaan hingga penayangan.

2) Program Berita. Merupakan program berita lokal yang diproduksi oleh redaksi biro pemberitaan Kompas Tv Makassar.

3) Kompas Tv Makassar. Sebuah stasiun lokal sebagi biro dari Kompas Tv yang berpusat di Jakarta. Selain merelay program dari Jakarta, juga memroduksi sendiri beberapa program, khusus untuk tayangan lokal, Makassar dan sekitarnya. 


\section{HASIL DAN PEMBAHASAN}

\section{Hasil Penelitian}

Manajemen pemberitaan sebuah media massa secara umum hampir sama, meskipun dalam praktiknya sering ada perbedaan antara televisi yang satu dengan televisi yang lainnya. Hal ini sangat wajar mengingat media hadir dengan tujuan dan kepentingan masing-masing media tersebut. Manajemen pemberitaan adalah proses pengelolaan materi pemberitaan melalui tahap-tahap perencanaan, pengorganisasian, penggerakan, dan pengawasan, yang mencakup proses peliputan, penulisan, sampai pada editing hingga menjadi berita yang layak untuk diyatangkan.

Kompas TV Makassar selaian menayangkan siaran relay dari Kompas TV pusat juga memiliki lima program lokal yang setiap harinya hadir bagi masyarakat Kota Makassar yaitu: (1) Embun Qalbu (2) I Love Makassar (3) Jappa-Jappa (4) Kompas Sulsel Pagi, dan (5) Kompas Sulsel Sore. Dua yang disebutkan terakhir, "Kompas Sulsel Pagi dan Kompas Sulsel Sore" merupakan program berita. Hasil penelitian ini menunjukkan:

1. Cara kerja divisi pemberitaan Kompas Tv, secara ketat diatur dalam rapat redaksi atau rapat proyeksi liputan setiap hari. Mereka melakukan rapat untuk proyeksi liputan keesokan harinya, sekaligus melakukan evaluasi pemberitaan dan tayangan berita pada hari itu juga. Hasil rapat redaksi langsung disampaikan ke kantor pusat Kompas Tv di Jakarta, khususnya tentang isu-isu pemberitaan yang akan diangkat.

2. Rapat perencanaan dipimpin langsung kepala biro Kompas $\mathrm{Tv}$ atau didelegasikan kepada produser eksekutif, sebagai penganggung jawab program berita "Kompas Sulsel Pagi" dan Kompas Sulsel Sore". Rapat redaksi wajib diikuti oleh seluruh kru redaksi, diantaranya: kameramen, video jurnalis, reporter, koordinator liputan, dan presenter, karena pada tahap inilah kerja bermula hingga hasil kerja ditayangkan.

3. Dalam hal mengorganisasi SDM dan penugasan, semuanya sudah ditentukan pada saat rapat redaksi. Kompas Tv misalnya menugaskan presenter dan kameramen berpasangan pada sebuah liputan. Atau bahkan kameramen bekerja sendiri, sehingga menjadi video jurnalis (VJ). Menentukan narasumber yang kredibel terkait berita yang akan diliput. Demikian pula kameramen atau VJ, sudah harus mengerti gambar apa saja yang harus diambil sebagai gambar pendukung berita.

4. Sebagai sebuah kerja tim, maka Kompas Tv melakukan sinergi pada semua bagian menjadi solid. Bukan hanya pada bagian pemberitaan, terutama ketika kerja redaksional telah selesai dan siap ditayangkan. Mulai dari crew studio yang terdiri atas kameraman studio, lightingman, dan floor director. Selain itu ada juga crew control room dan master control room, ada audioman, switcherman, dan lain sebagainya.

5. Tahap pengawasan juga dilakukan setiap hari. Evaluasinya berlangsung pada rapat redaksi. Khusus tentang pemberitaan, kontrol dilakukan secara berjenjang, mulai dari atasan yakni kepala biro hingga kepada kameramen atau VJ. 


\section{Pembahasan}

\section{Fungsi Perencanaan (Planning)}

Produksi program pada sebuah stasiun televisi bukan pekerjaan individual, melainkan kerja tim. Baik untuk program entertain ataupun program news. Pelru manajemen yang baik agar semua berjalan lancar. Hakikat fungsi manajemen dari Terry adalah apa yang direncakan, itu yang akan dicapai. Sehingga fungsi perencanaan harus dilakukan sebaik mungkin, agar dalam pelaksanaanya bisa berjalan dengan baik serta segala kekurangan bisa diatasi. http://studimanajemen.blogspot.co.id/2012/08/fungsimanajemen-menurut-georgeterry.htlml (diakses pada 22 Mei 2016). Perencanaan matang melalui rapat redaksi itulah yang dilakukan Kompas Tv Makassar. Sebagaimana bagan berikut ini:

Gambar 1.

Skema Rapat Redaksi Kompas TV Makassar

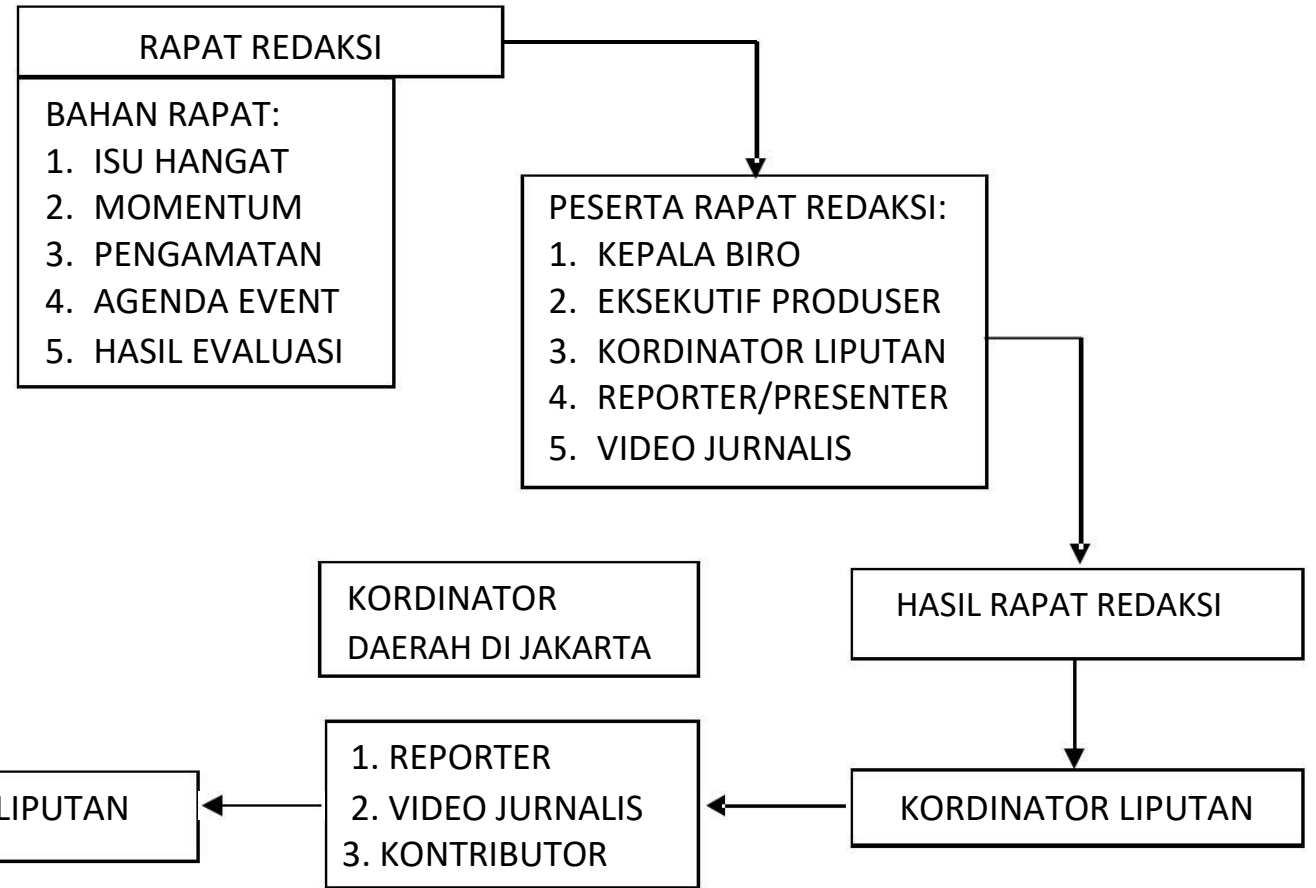

Sumber: Diolah dari hasil penelitian

Menurut Kepala Biro Kompas TV Makassar, Saffri Sitepu, rapat redaksi wajib diikuti oleh kru redaksi, sebagaimana diungkapkan berikut ini:

"Rapat redaksi di kompas tv ini sifatnya wajib. Biasanya dilaksanakan setelah tayangan program Kompas Sulsel Sore. Setelah rapat redaksi, saya akan melaporkan ke kordinator daerah di Kompas Tv pusat, bahwa Makassar besok akan bermain isu liputan ini, mengambil angle ini, dan lain-lain." 
Kewajiban menghadiri rapat redaksi, selain untuk membahas perencanaan, juga dimaksudkan agar seluruh kru melakukan persiapan berupa riset isu maupun narasumber berita. Maya Ochtaria, eksekutif produser sekaligus produser program berita "Kompas Sulsel Pagi" dan "Kompas Sulsel Sore", mengatakan bahwa tujuan rapat redaksi selain perencanaan peliputan keesokan harinya, juga menentukan siapa-siapa saja reporter atau video jurnalis yang akan ditugaskan.

Proses produksi pemberitaan di Kompas TV Makassar dimulai dari melakukan rapat redaksi atau rapat proyeksi. Dalam rapat ini terlebih dahulu akan dibahas hasil dari rapat evaluasi program yang sudah tayang. Setelah itu seluruh tim memberikan ide atau gagasan berdasarkan hasil pengamatan masing-masing untuk didiskusikan menjadi bahan liputan keesokan harinya. Selain ide dari masing-masing tim biasanya juga akan dibahas informasi yang masuk dari berbagai sumber baik itu dari media cetak, online, maupun elektronik.

Untuk meliput sebuah peristiwa, maka paling sedkit dalam satu tim liputan akan melibatkan dua orang, yaitu reporter dan kameramen, bahkan bisa sampai tiga atau empat orang ketika liputan pada malam hari karena akan ada yang bertugas sebagai lightingman atau juru lampu, yang akan mengatur sistem pencahayaan.

Para reporter dan video jurnalis Kompas Tv Makassar sebelum berangkat menuju lokasi liputan dengan berbekal tugas atau proyeksi dari korlip, harus juga mencari informasi mengenai berita yang akan diliput. Membuat janji wawancara dengan narasumber. Membuat daftar pertanyaan dan mengetahui lokasi liputan, agar tidak mengalami kendala teknis saat di lapangan, merupakan bagian dari perencanaan di tingkat reporter. Sebagaimana diungkapkan Rama Pratama, video jurnalis Kompas TV Makassar: "Setelah rapat redaksi, biasanya saya mencari materi terkait tentang liputan esok hari, agar saat di lapangan, sudah bisa mengetahui sedikit tentang liputan itu”.

\section{Fungsi Pengorganisasian (Organizing)}

Pengorganisasian merupakan hal penting dalam rangka mencapai tujuan organisasi. Sebelum reporter dan video jurnalis Kompas Tv Makassar turun lapangan, mereka akan melakukan persiapan seperti rapat kordinasi terlebih dahulu untuk membahas materi yang akan mereka liput. Nanti di lapangan akan seperti apa. Tentang hal ini, Muhammad Taufik Asdar, Kordinator Liputan Kompas TV Makassar, mengatakan:

"Pembentukan tim liputan, dilakukan dengan memasangkan video jurnalis dengan reporter. Tim liputan di Kompas TV sendiri setiap harinya berganti, agar tercipta keakraban antara reporter dengan video jurnalis. Namun adakalanya tim liputan tidak harus dua orang, misalnya bisa saja seorang kameramen menjadi video jurnalis turun liputan sendiri. Jadi tanpa reporter".

Teknik pengorganisasian ini berdasarkan kebutuhan di lapangan. Termasuk ketika reporter dan video jurnalis terkadang menemukan peristiwa baru di luar dari tugas proyeksi mereka. Prinsip koordinasi dengan level manajemen lebih tinggi harus dilakukan. Dalam hal ini dikordinasikan atau dilaporkan kepada kordinator liputan 
atau produser yang bertugas di kantor Kompas TV Makassar. Tujuannya agar mendapatkan persetujuan dan arahan sesuai kebijakan dan kepentingan redaksi, apakah berita tersebut diliput atau tidak.

Persaingan menghasilkan berita televisi yang menarik perhatian pemirsa menjadi prioritas Kompas TV Makassar. Oleh sebab itu reporter dan video jurnalis harus cermat mencari berita di lapangan. Setidaknya memuat lima hal: (1) berita berdasarkan isu hangat, (2) berita berdasarkan agenda event, (3) berita yang berkelanjutan, (4) berita berdasarkan momentum, dan (5) berita berdasarkan pengamatan (Andi Fachruddin, 2012: 80).

Di Kompas TV Makassar reporter akan berfungsi sebagai produser lapangan atau produser liputan. Ia memimpin liputan tersebut, sehingga berwenang mengarahkan video jurnalis mengenai gambar apa yang dibutuhkan untuk melengkapi laporan beritanya. Video jurnalis dan lightingman, harus tunduk pada reporter. Namun tidak menutup kemungkinan video jurnalis bersama tim liputan lainnya bisa memberi masukan kepada reporter selaku produser lapangan. Walaupun reporter berkapasitas produser, ia juga harus menjaga team work dengan baik, sehingga kerja sama antara satu dan yang lainnya sangat diperlukan dalam rangka menghasilkan liputan berkualitas.

Gambar 2.

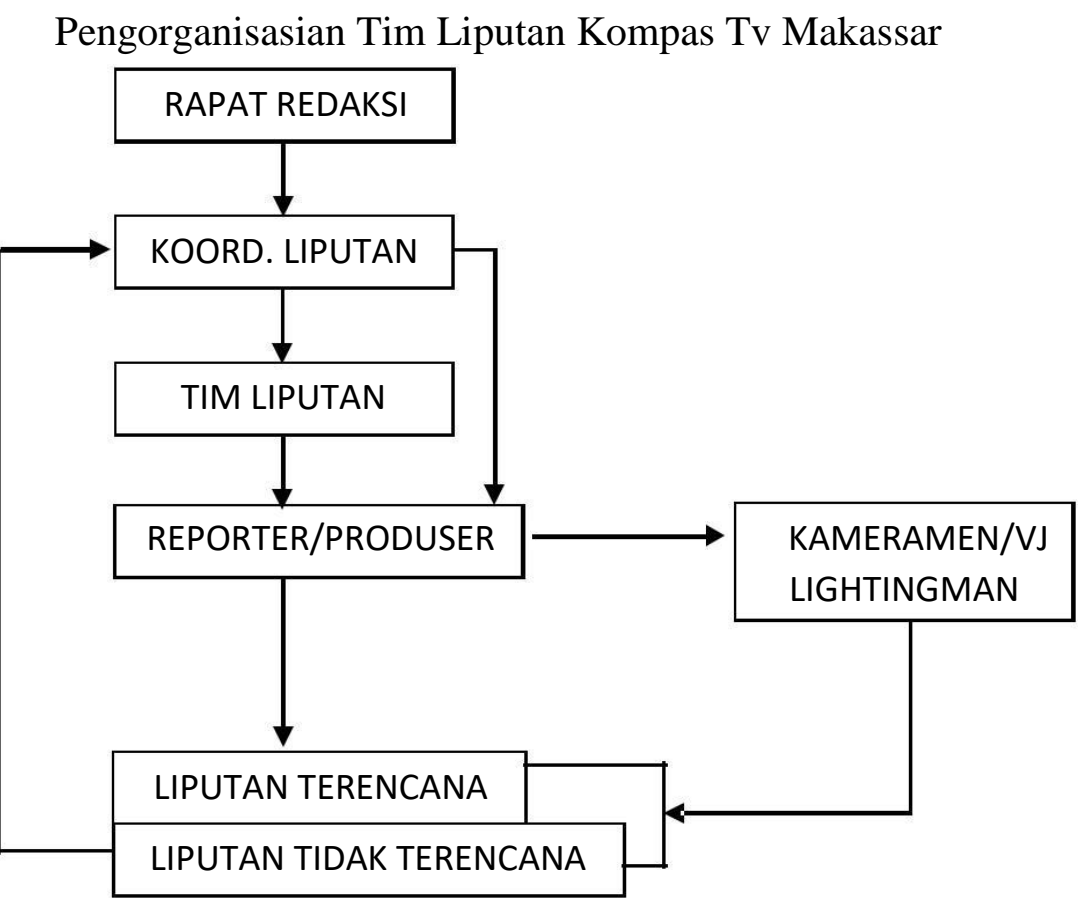

Sumber: Diolah dari hasil penelitian 


\section{Fungsi Penggerakan (Actuating)}

Sebagai team work, divisi pemberitaan butuh manajerial yang baik. Menggerakkan divisi pemberitaan, bukan hanya soal eksekusi liputan lapangan, tetapi juga bagaimana eksekusi setelahnya. Kembali dari liputan kameramen/VJ melakukan capture gambar ke komputer editor. Setelah itu video jurnalis akan membuat daftar gambar atau shoot list untuk memudahkan editor mengedit.

Seorang editor Kompas TV Makassar harus patuh terhadap peraturanperaturan tentang gambar seperti apa yang layak disiarkan atau tidak, apabila dalam daftar gambar yang diserahkan ada gambar yang melanggar kode etik jurnalistik, maka hal harus dikordinasikan ke video jurnalis. Gambar yang dianggap layak dan relevan, selanjutnya disusun berdasarkan naskah berita yang telah diedit produser atau eksekutif produser. Selanjutnya dapat dilihat pada gambar di bawah ini:

Gambar 3.

Skema Alur Naskah dan Video di Kompas TV Makassar

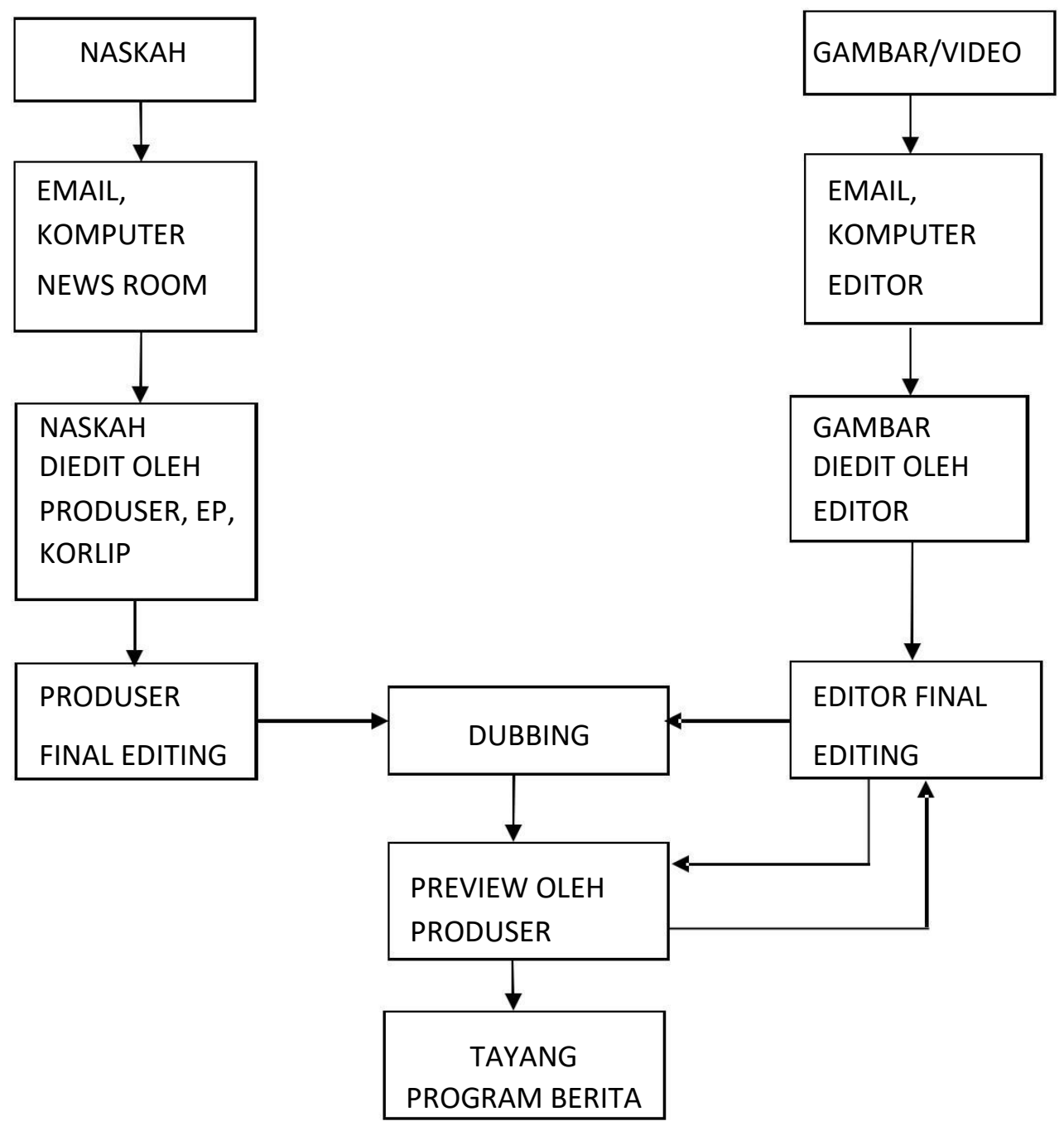

Sumber: Diolah dari hasil penelitian 
Menggerakkan organisasi, termasuk salah satu kemampuan manajerial mendelegasikan tugas dan tanggung jawab kepada masing-masing SDM. Tidak perlu ada pertanyaan lanjutan yang terlalu menguras tenaga ketika semua SDM harus bergerak. Rama Pratama, video jurnalis Kompas TV Makassar, misalnya, tidak pelru lagi bertanya bagaimana merekam gambar yang dibutuhkan untuk pemberitaan. Rama sudah harus tahu bahwa pinsip pengambilan gambar pada kamera televisi, harus memastikan kamera seolah-olah mewakili mata penonton.

\section{Fungsi Pengawasan (Controlling)}

Tahap penayangan merupakan tahap akhir dari proses peliputan. Setelah proses peliputan dari tahap perencanaan, proses produksi, proses pengeditan naskah dan gambar hingga on-air selesai, selanjutnya adalah melakukan rapat evaluasi. Kegiatan dalam fungsi pengawasan (Fachruddin, 2016: 16), meliputi evaluasi keberhasilan dan pencapaian tujuan dan target, mengambil langkah klarifikasi dan koreksi atas penyimpangan yang terjadi, dan melakukan beberapa alternatif sebagai solusi.

Divisi redaksi pemberitaan Kompas Tv, menjadikan forum rapat evaluasi yang dipimpin oleh eksekutif produser dan dilaksanakan setelah penayangan program berita "Kompas Sulsel Sore", sebagai forum evaluasi keseluruhan produksi berita. Dalam rapat evaluasi akan dibahas kesalahan-kesalahan yang terjadi. Mulai dari proses peliputan, penulisan naskah, pengambilan gambar, proses pengeditan, sampai kepada proses penayangan berita.

Rapat evaluasi bertujuan agar kesalahan-kesalahan yang terjadi hari ini diharapkan tidak terulang lagi keesokan harinya. Selain itu rapat evaluasi juga dilakukan untuk membenahi kekurangan, mengetahui baik buruknya tayangan berita yang disiarkan, serta sebagai ajang saling koreksi terhadap diri masingmasing kru. Saran perbaikan akan disampaikan oleh kepala biro atau eksekutif produser yang memimpin rapat evaluasi. Hasil dari rapat evaluasi ini akan dikirimkan ke Kepala Biro dan ke Kompas TV Pusat melalui email Kordinator Liputan.

Meski rapat redaksi menjadi forum evaluasi harian secara keseluruhan, pengawasan juga telah berlangsung pada masing-masing level. Niluh Puspa, reporter sekaligus presenter dan produser lapangan Kompas Tv Makassar, menjelaskan: "Selesai liputan saya ke ruangan redaksi melihat proses pengeditan naskah yang saya kirimkan dari lokasi liputan, yang sedang diedit oleh kordinator liputan, produser, atau eksekutif produser.

Pada saat proses editing naskah dan gambar berlangsung, reporter dan video jurnalis harus mendampingi produser dan editor. Tujuannya, bila naskah yang sedang diedit kekurangan data, maka reporter harus bisa memberikan penjelasan demi kesempurnaan informasi yang disiarkan. Begitu pula dengan video jurnalis harus selalu berada di samping editor, karena video jurnalis lah yang tahu gambar-gambar mana yang bagus dan berkualitas yang bisa ditayangkan. 


\section{PENUTUP}

\section{Kesimpulan}

Berdasarkan hasil penelitian dan pembahasan, dapat diketahui bahwa divisi redaksi program berita Kompas Tv Makassar, menerapkan dengan sangat ketat empat fungsi manajemen terhadap seluruh proses kerja kru redaksi. Mulai dari perencanaan, pengelolaan organisasi, menggerakkan seluruh sumber daya, hingga pengawasan terhadap eksekusi dari seluruh perencanaan yang dihasilkan melalui rapat redaksi. Tidak ada fungsi manajemen lebih menonjol di antara yang lainnya. Namun komitmen pada lembaga rapat redaksi sebagai forum pengambilan keputusan tertinggi atas isu liputan, pembentukan tim liputan, eksekusi di lapangan, dan seluruh perencanaan serta hasil evaluasi, merupakan suatu keharusan bagi seluruh kru divisi pemberitaan Kompas Tv Makassar.

Manajemen redaksi divisi pemberitaan Kompas Tv Makassar, bahkan telah menerapkan empat fungsi manajemen sekaligus dalam sekali rapat redaksi. Meliputi planning, organizing, actuating, dan controlling. Implementasi planning dilakukan melalui perencanaan liputan dan proyeksi. Organizing tercermin pada bagaimana seluruh kru bekerja sesuai kedudukannya, terkait wewenang dan tanggung jawabnya. Termasuk ikut memberi masukan dan kritik. Fungsi actuating terimplementasi melalui bagaimana mereka mengeksekusi perencanaan dalam bentuk tugas masing-masing, sejak liputan hingga penayangan. Sementara fungsi controlling tampak pada evaluasi menyeluruh atas hasil kerja seluruh kru. Evaluasi termasuk pula upaya perbaikan dari perencanaan yang meleset atau tidak sesuai target yang diharapkan.

\section{Saran}

1. Sebagai stasiun televisi biro Makassar yang juga berkewajiban melaporkan berita ke stasiun pusat Jakarta, maka redaksi pemberitaan Kompas Tv Makassar agar lebih produktif mengirimkan berita ke Jakarta, sehingga informasi penting dari Kota Makassar dan Sulsel umumnya, dapat mewarnai pemberitaan secara nasional.

2. Kepada peneliti selanjutnya, yang hendak meneliti Kompas Tv Makassar, agar melakukan penelitian dari segi strategi bisnisnya sebagai televisi biro yang, selain berkonten siaran relay Jakarta, juga punya program lokal.

\section{DAFTAR PUSTAKA}

Arifin, Eva. 2010. Broadcasting to be A Broadcaster. Yogyakarta: Graha Ilmu.

Baksin, Askurifai. 2006. Jurnalistik Televisi: Teori dan Praktik. Bandung:

Simbiosa Rekatama Media.

Deddy Iskandar Muda. 2003. Jurnalistik Televisi: Menjadi Reporter Profesional,.

Bandung: PT. Remaja Rosdakarya.

Fachruddin, Andi. 2016. Manajemen Pertelevisian Modern, Yogyakarta: Andi. 
Mabruri KN, Anton. 2013. Manajemen Produksi Program Acara TV, Format Acara Non-Drama, News, \& Sport, Jakarta: PT. Grasindo.

Moleong, Lexy J. (2007) Metodologi Penelitian Kualitatif, Penerbit PT Remaja Rosdakarya Offset, Bandung.

Morissan. 2008. Manajemen Media Penyiaran: Strategi Mengelola Radio \&. Televisi. Jakarta: Kencana Prenada Media.

Sutopo, H.B.. 2002. Metodologi Penelitian Kualitatif. Surakarta : UNS Press.

Sugiyono. 2009. Metode Penelitian Kuantitatif, Kualitatif dan R\&D, Bandung: Alfabeta.

http://studimanajemen.blogspot.co.id/2012/08/fungsimana-jemen-menurutgeorge-terry.html. 